\title{
SÄO PAULO NA PRIMEIRA REPÚBLICA: DEMOCRACIA E OPOSIÇÃO LIBERAL
}

\author{
PRADO, Maria Ligia C. A Democracia I'ustrada (O Partido Democrático de \\ São Paulo, 1926-1934). São Paulo: Ática, 1986, 197 p.
}

Res. por Silvia Levi-Moreira ${ }^{1}$

A preocupação com as oposições políticas no Brasil tem merecido crescente destaque na historiografia atual. Isso talvez se deva, em parte, às novas circunstâncias políticas originadas no processo de redemocratização do país. Por outro lado, há um esforço de revisão de uma historiografia que se centrou na consagração de momentos homogêneos e fatos acabados. A tese de Doutoramento de Maria Lígia Prado publicada em 1986, pela Coleção Ensaios da Editora Ática, insere-se nesse esforço.

O regime republicano brasileiro, desde o seu estabelecimento em 1889 , coexistiu com movimentos de caráter oposicionista. Em São Paulo, o partido dominante e praticamente único no poder - o Partido Republicano Paulista (PRP) conviveu, ao longo de toda a sua existência, com diversas dissidências que acabaram se consolidando na formação de um partido de oposição: o Partiđio Democrático (PD).

Fundado em 1926, o PD contou com a participação de indivíduos vinculados, em sua maioria, à Faculdade de Direito e ao jornal "O Estado de São Paulo", como Júlio de Mesquita, Waldemar Ferreira, Francisco Morato e Marrey Junior. Já no manifesto-programa do PD defendiam-se os princípios liberais, consolidados na Constituição e a reforma da lei eleitoral (para garantir a lisura

Mestre em História Social - FFLCH/USP. 
das eleições). Além disso, abordava-se a "questão social", juntamente com propostas visando ao desenvolvimento da lavoura, do comércio e da indústria. $O$ partido elegeu deputados federais e estaduais, apesar das hostilidades do PRP. Em 1927, tentou-se organizar o PD a nível nacional. Os núcleos regionais continuaram, no entanto, independentes. A nível nacional, a agremiação - já então PDN - apoiou Getúlio Vargas à presidência da República. Isto traduzia o fortalecimento, dentro do partido, da corrente que defendia o caminho parlamentar para enfrentar o situacionismo, levando os democráticos a apoiar a Aliança Liberal na sucessão presidencial em 1930.

Dentro das normas democráticas, o PD pretendia por fim aos "desmandos oligárquicos e governistas", implantados em São Paulo pelo PRP. Entretanto, após as eleições municipais fraudulentas realizadas em 1928, o PD viu-se obrigado a repensar o caminho legalista. Somente em 1930, os democráticos iriam aderir à luta armada sem, no entanto, incorporarem definitivamente o "caminho revolucionário" como estratégia do partido.

Os desentendimentos com Getúlio Vargas levariam os democráticos a aproximar-se do antigo inimigo (o PRP) e a abandonar rapidamente o seu apoio à Revolução de 30. A perda progressiva do controle do Estado paulista, com a interventoria de João Alberto, era tida como uma humilhação e "invasão" de São Paulo. As vozes separatistas ganhavam força na virada da década. Assim, em 1932, como afirma Maria L. Prado, substituiu-se a bandeira da "democracia" pela bandeira "Tudo por São Paulo".

O rompimento definitivo com o Governo Federal se concretizaria na adesão à Frente Única e ao movimento armado em 1932. Essa movimentação, no entanto, não se fez de forma homogênea, isto é, havia dissensões dentro do próprio PD. Após 3 meses de luta, São Paulo - e com ele o PD - perdia a batalha e seus políticos eram obrigados a, momentaneamente, voltar-se para interesses que diziam respeito apenas ao próprio Estado.

O importante a lembrar, conforme mostra Maria L. Prado, é que a união com o PRP selaria o esvaziamento e a decadência definitiva do PD: "Era impossível, do ponto de vista ideológico, reorganizar outra plataforma programática para o Partido Democrático de São Paulo. O partido se esgotava em si mesmo" (p. 135). Em 1933 o PD desaparecia mas, muitos de seus líderes participariam do Partido Constitucionalista em 1934 e, posteriormente, da União Democrática Nacional (UDN) em 1945. 
Após historiar as lutas políticas empreendidas pelo PD, Maria L. Prado estabelece, no último capítulo, as ligações do partido com os diferentes setores da sociedade, fornecendo elementos para a compreensão do significado de um partido de oposição na década de 20 .

No que se refere ao café - que garantia o predomínio econômico do Estado de São Paulo - a pesquisa mostra que não havia divergência entre PRP e PD quanto à política oficial com relação ao produto. As propostas econômicas para as crises na cafeicultura eram encaminhadas pelas associações de agricultura e não pelos partidos. Maria L. Prado acredita que os debates econômicos no período favoreceram o nascimento do partido oposicionista. A autora discorda, porém, das análises que procuram estabelecer vínculos estreitos entre o surgimento do PD e setores descontentes com a política oficial do café, implementada pelo PRP. Conclui que não havia diferença concreta, do ponto de vista econômico, entre PD e PRP. Interesses econômicos diversos coexistiram dentro do PD. O mesmo se aplica aos interesses da inđústria apesar de, no geral, os industriais terem permanecido ligados basicamente ao PRP. O que não significa que o PD tivesse assumido uma postura antiindustrialista. Nele "não havia claramente uma defesa da industrialização, como também ali não se encontrava o seu oposto" (p. 158).

Após discutir a inter-relação PD e interesses econômicos do Estado de São Paulo é preciso então dar uma resposta ao porquê da formação de um partido de oposição em 1926. A própria autora responde: "O Partido Democrático surgiu com um projeto específico para fazer frente ao movimento social que avançava 'perigosamente', podendo por em risco as estruturas político-sociais vigentes. A relação entre classe dominante e classe dominada estava colocada de forma límpida pelo governo (sustentado pelo Partido Republicano Paulista): a dominação se exercia através da repressão pura e simples" (p. 158). Os opositores elaboraram um outro projeto de dominação social, calcado nos princípios liberais e democráticos.

Ao tratamento repressivo dispensado à "questão social" pelo governo paulista, o PD antepôs a proposta da lei e da ordem, chegando a reconhecer os direitos de reivindicação da classe trabalhadora. Maria L. Prado considera que, além do fato do PD ter contribuído para a derrota das forças perrepistas, o partido teve um importante papel na difusão de certas bandeiras democráticas, como a do voto secreto e da participação eleitoral. O fundamental, no entanto, era o projeto alternativo de poder, que divisava a "questão social" não mais enquanto 
PRADO, Maria Ligia C. A Democracia llustrada. (O Partido Democrático de Săo Paulo, 1926-1934).

uma "questão de polícia", mas sim como uma "questão de direito". Este projeto se constitui "na fórmula mais adequada encontrada pela classe dominante para apagar e neutralizar os antagonismos sociais e as oposições de classe" (p. 176).

Num momento em que se desenrolam eventos importantes para a democratização - e a modernização - do país, nada é mais atual do que a publicação de trabalhos que acompanham as trajetórias das diversas oposições no Brasil. O livro de Maria L. Prado atende muito bem a essa demanda. Muitas das bandeiras de luta defendidas pelos democráticos de 26 continuam a vigorar nos dias de hoje. Dessa forma, o trabalho de Maria L. Prado torna-se leitura utilíssima para aqueles que quiserem compor o quadro mais amplo das ambiguidades, das continuidades e da inserção das oposições na vida política do país. 